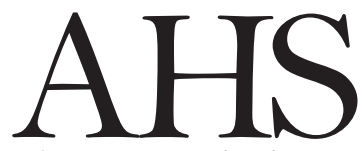

Advances in Horticultural Science

\title{
Alleviation the effects of salinity stress using titanium dioxide nano and bulk particles in Echinacea seeds and seedlings
}

\author{
H. Behnam, H. Feizi ${ }^{(*)}$, M. Alipanah \\ Department of Plant Production, University of Torbat Heydarieh, Torbat \\ Heydarieh, Iran.
}

Key words: Abiotic stress, germination percentage, medicinal plant, salt.

OPEN ACCESS

\footnotetext{
${ }^{(*)}$ Corresponding author:

h.feizi@torbath.ac.ir

hasanfeizi@yahoo.com
}

Citation:

BEHNAM H., FEIZI H., ALIPANAH M., 2021 -

Alleviation the effects of salinity stress using titanium dioxide nano and bulk particles in Echinacea seeds and seedlings. - Adv. Hort. Sci., 35(4): 351360.

\section{Copyright:}

(c) 2021 Behnam H., Feizi H., Alipanah M. This is an open access, peer reviewed article published by Firenze University Press

(http://www.fupress.net/index.php/ahs/) and distributed under the terms of the Creative Commons Attribution License, which permits unrestricted use, distribution, and reproduction in any medium, provided the original author and source are credited.

Data Availability Statement:

All relevant data are within the paper and its Supporting Information files.

Competing Interests:

The authors declare no competing interests.

Received for publication 4 May 2021 Accepted for publication 29 October 2021

\begin{abstract}
This study aimed to investigate the effect of nanoparticles and nonnanoparticles of titanium dioxide on germination indices of Echinacea under salinity stress. Experimental treatments included nano and bulk particles of titanium dioxide at concentrations of $0,10,50,100$ and $150 \mathrm{mg} / \mathrm{l}$ and salinity stress from $\mathrm{NaCl}$ at levels of $0,-3,-6$ and -9 bar. The results showed that Echinacea is sensitive to high salinity stress levels ( -6 and -9 bar). The use of nano and non-nano titanium dioxide treatment improved some traits under severe salinity stress. The germination percentage did not occur at salinity levels of -6 and -9 bar, but the addition of nano titanium dioxide with a concentration of $150 \mathrm{mg} / \mathrm{l}$ and $50 \mathrm{mg} / \mathrm{l}$ non-nano increased germination by $50.6 \%$. Application of nano titanium dioxide increased the seedling weight in control by $1.28 \mathrm{mg}$ to $4.26 \mathrm{mg}$ in the treatment of $150 \mathrm{mg} / \mathrm{I}$ nanoparticles. The application of nano and bulk titanium dioxide could significantly reduce the negative effect of high salinity stress levels. This can be a valuable and hopeful solution to solve the problem of salinity stress in Echinacea.
\end{abstract}

\section{Introduction}

Echinacea (Echinacea purpurea) is a perennial herbaceous plant of the chicory family (Asteraceae) and is native to the rocky areas, highlands and Atlantic plains of North America and Canada (Raman et al., 2004). The most important medicinal property of this plant, a selected plant of the World Health Organization, is to strengthen the immune system (Sun et al., 1999). This plant contains valuable active ingredients such as flavonoid compounds, alkaloids and chicoric acid (Sandra, 2004). The most important substances in Echinacea are essential oils of borneol and alpha-pinene (Faravani et al., 2016). In recent years, low rainfall and uncontrolled withdrawal of groundwater resources in the country, followed by an increase in groundwater salinity, has become a significant problem for agriculture, which in addition to reducing fresh water resources, has also increased soil salinity. Therefore, using new technolo- 
gies to eliminate and reduce the effects of salinity stress on plants is inevitable. One of the advanced technologies that can be used in this field is the use of nanoparticles. Undoubtedly, by taking advantage of nanotechnology as an emerging advanced technology in the agricultural sector, desirable results can be achieved, including ensuring food security and the development of sustainable and environmentally friendly agriculture in developing countries and regions of the world (Kamali et al., 2018).

One of the most important nanoparticles that has been widely used in various sciences is titanium dioxide nanoparticles. Titanium dioxide nanoparticles appear to stimulate plant root and shoot growth by stimulating plant metabolism and increasing cell division. A study by Karami and Sepehri (2018) stated that the application of titanium dioxide nanoparticles improved the growth and photosynthetic performance of barley under salinity stress. This improvement was reported due to increased antioxidant activity in the presence of nanoparticles. Navarro et al. (2008) stated that nanoparticles might create new larger pores in the seed coat that facilitate the entry of water and oxygen and increase seed germination. Faraji and Sepehri (2019) showed that the application of titanium dioxide nanoparticles increased germination and morphological traits of wheat seedlings under drought stress. Under moderate and severe stress conditions, the application of titanium dioxide and nitroprusside nanoparticles alone or in combination improved the average germination time of wheat seeds by $56 \%$. The positive effects of titanium dioxide nanoparticles on increasing plant growth, antioxidant enzyme activity, soluble sugars, amino acid and proline content and reduction of $\mathrm{H}_{2} \mathrm{O}_{2}$ and melonic dihydrogenase in beans under salinity stress have been reported (Abdel Latef et al., 2018). Khan (2016) reported a decrease in salinity stress in tomatoes by foliar application of titanium dioxide nanoparticles at a concentration of $20 \mathrm{ppm}$ by improving agronomic traits, leaf chlorophyll content, phenolic and antioxidant capacity, antioxidant enzyme activity and fruit yield. Titanium can act as a stimulant for the plant, activating the immune system against stress. Feizi et al. (2020) showed that application of 300 ppm of titanium dioxide nanoparticles improved the mean germination time (MGT) and seed germination rate of lentil by $39 \%$ and $62 \%$, respectively. Nasir Khan (2016) reported using $20 \mathrm{mg} /$ lit nano- $\mathrm{TiO}_{2}$ on tomato plant improved activities of carbonic anhydrase, nitrate reductase, SOD and POX and accumulation of proline and glycine betaine in salinity stress condition.

Gohari et al. (2020) showed that the application of titanium dioxide nanoparticles offset the adverse effects of salinity stress on agronomic traits of Dracocephalum moldavica. Application of $100 \mathrm{mg} / \mathrm{l}$ titanium dioxide nanoparticles under salinity stress of 50 and $100 \mathrm{mM}$ sodium chloride increased the activity of antioxidant enzymes and decreased $\mathrm{H}_{2} \mathrm{O}_{2}$ concentration. The results of a study on the effect of osmotic and salinity stress on germination and seedling growth indices of Echinacea purpurea and Cynara scoolymus showed that Echinacea is sensitive to low and medium levels of salinity stress (Amiri et al., 2010). Also, with increasing the intensity of osmotic stress, the root length of Echinacea and shoot length of both plants decreased until it reached zero at the levels of -10 and -14 bar for Echinacea and Artichoke, respectively (Amiri et al., 2010). In a study on the effect of different osmotic potentials of sodium chloride and calcium chloride salts on the germination characteristics of Echinacea seeds, it was observed that with increasing salt concentration, all germination traits significantly $(p \leq 5 \%)$ are reduced, so that in the potential of -9 bar, the percentage and rate of germination decreased by $50 \%$ and seed vigor by $83 \%$ (Ebrahimi Anjeshshi et al., 2011). Lyu et al. (2017) stated that seeds soaked in titanium dioxide nanoparticles showed a higher germination rate, more root growth and improved seedling growth. Nanoparticles can enter the seed coat and increase the entry of water and nutrients and improve seed growth. But their toxic effects also occur in seeds. Younes et al. (2020) reported that the application of $100 \mathrm{ppm}$ of $\mathrm{TiO}_{2}$ and $\mathrm{ZnO}$ nanoparticles on three species of the Solanaceae family significantly improved their germination traits and reduced their average germination time. Kamali et al. (2018) showed that at $75 \mathrm{mM}$ salinity, foliar application of titanium dioxide nanoparticles in $15 \mathrm{ppm}$ treatment increased the number of flowers in Petunia hybrida plant from 5.6 to 9.3. Also, the highest shoot fresh weight was observed in the treatment of 15, 20 and $40 \mathrm{ppm}$ foliar application of titanium dioxide nanoparticles.

According to research, it seems that the use of nanotechnology can reduce the adverse effects of salinity stress on seeds and plant growth. Therefore, the present study was conducted to investigate the effect of titanium dioxide nano and bulk particles on seed germination and seedling growth of Echinacea in modulating salinity stress conditions. 


\section{Materials and Methods}

In order to investigate the effect of nanoparticles and non-nanoparticles of titanium dioxide on germination indices of Echinacea under experimental salinity stress, an experimental study was performed in the Laboratory of Medicinal Plants of the University of Torbat Heydarieh, Iran. To perform the study, 100 grams of Echinacea seeds were purchased from the Agricultural and Natural Resources Research Center of Isfahan Province. The seeds were carefully threshed and 2700 seeds were isolated for testing. This experiment was conducted as a factorial layout based on a completely randomized design with four replicates.

Each of the experimental steps has 36 integrated treatments, including nine levels of zero (control) titanium dioxide concentration, 10,50, 100 and 150 $\mathrm{mg} / \mathrm{l}$ of nanoparticles and 10, 50, 100 and $150 \mathrm{mg} / \mathrm{l}$ of bulk particles and four levels of salinity stress were zero (control), $-3,-6$ and -9 bar in three replications. In these experiments, sterile Petri dishes and filter paper with a diameter of nine $\mathrm{cm}$ were used as the culture medium (Top paper culture method or TP).

\section{Exert treatment}

The filter papers were wrapped in aluminum foil for each stage of culture and disinfected in an autoclave at $120^{\circ} \mathrm{C}$ for 20 minutes. Seeds were disinfected using $10-14 \%$ sodium hypochlorite for 30 seconds and then washed thoroughly with distilled water three times each time for three minutes until the disinfectant was completely removed from the seed surface. The work surface and all utensils and utensils used were disinfected using $70 \%$ ethanol.

In each Petri dish, 25 disinfected seeds were placed at a suitable distance from the bed of filter paper. Then $5 \mathrm{ml}$ of the prepared solutions were added and the lid of the Petri dishes was closed using para film to prevent evaporation of the material and the solution was not added until the end of the test period. Petri dishes were placed in a germinator with a temperature of $25^{\circ} \mathrm{C}$ and a humidity of $60 \%$ at $16 / 8$ hours length in day/night.

\section{Preparing saline and $\mathrm{TiO}_{2}$ solution}

To prepare the final solution of the treatments, each level of titanium dioxide factor must be mixed separately with each of the salinity stress levels in a ratio of $1: 1$ to obtain a homogeneous solution and then applied to the seeds. For this purpose, titanium dioxide levels, as well as salinity stress, should be prepared in double concentration to achieve the desired concentration after mixing them; Therefore, to prepare $100 \mathrm{ml}$ of each of the concentrations of $20,100,200$ and $300 \mathrm{mg} / \mathrm{l}$ of nanoparticles and nonnano titanium dioxide, the amounts of 5, 25, 50 and $75 \mathrm{ml}$ of stock solution, respectively. It was poured separately and each of them was brought to a volume of $100 \mathrm{ml}$ with the help of distilled water. To prepare different concentrations of salinity, $\mathrm{NaCl}$ salt made in Germany (Merck) was used based on Richards method (Richards, 1954). Different salinity levels were prepared with double concentration. Then, $10 \mathrm{ml}$ of titanium dioxide solution was mixed with $10 \mathrm{ml}$ of saline solution at the desired stress level in a Beaker and homogenized.

Nanosized $\mathrm{TiO}_{2}$ powder was AEROXIDE ${ }^{\circledR} \mathrm{TiO}_{2}$ P25, supplied by Degussa GmbH Company. Specific surface area of nanosized TiO2 was $50 \mathrm{~m}^{2} \mathrm{~g}^{-1}$, average primary particle size was $21 \mathrm{~nm}$ and purity was $>99.5 \%$. The size of $\mathrm{TiO}_{2}$ nanoparticles (Fig. 1) and bulk particles (Fig. 2) were determined. In order to gain accurately dispersed and stable $\mathrm{TiO}_{2}$ suspensions of each concentration, an ultra-sonication treatment was applied to bulk and nanoparticles $\mathrm{TiO}_{2}$ powders dispersed in water for 15 minutes.
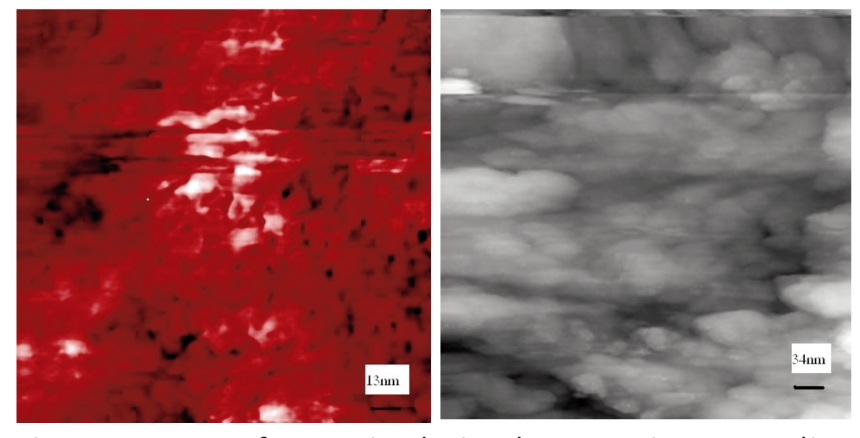

Fig. 1 - Images of nanosized $\mathrm{TiO}_{2}$ by Scanning Tunneling Microscope (STM).

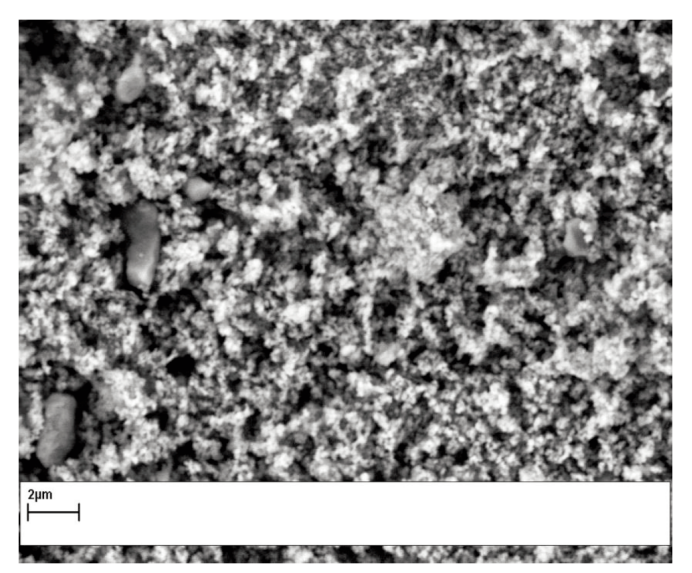

Fig. 2 - Image of bulk $\mathrm{TiO}_{2}$ particles by Scanning Electron Microscope (SEM). 


\section{Measurement methods}

Daily counting started from the day after planting at a specific time and continued until the 21st day (ISTA, 2009). Seeds with a root length of more than two millimeters were counted as germinated seeds (ISTA, 2009). At the end of the day, 10 seedlings were randomly selected from each experimental unit and the length of roots, stems and seedlings were measured and recorded using millimeter paper. The stems and roots were separated and each was taken in separate paper bags in an oven at $70^{\circ} \mathrm{C}$ for 24 hours and then weighed with a digital scale to the accuracy $0.0001 \mathrm{~g}$. To determine the germination rate of Maguire formula (Maguire, 1982), the mean germination time (MGT) (Matthews and KhajehHosseini, 2007) and the mean daily germination (MDG) (Azimi et al., 2013) from the following equations used:

$$
\text { Germination rate }(G R)=(a / 1)+(b-a) / 2+(c-b) / 3+\ldots .[n-(n-1)] / n
$$

Where GR indicates the germination rate in terms of germinated seeds per day, $a, b, c \ldots n$ indicates the number of germinated seeds after $N \ldots 3,2,1$ day after dewatering.

$$
\mathrm{MGT}=[\Sigma(F \cdot X)] /(\Sigma F)
$$

MDG = Germination\% / total experiment days

In Equation (2), MGT: mean germination time (days), $F$ : the number of new germinated seeds per day of count $X$ and $X$ days of counting. Equation (4) and (5) were used to calculate the seed vigor index (Vashith and Nagarajan, 2010):

Vigor index I = germination $\% \mathrm{x}$ seedling length in $\mathrm{cm}$ (shoot + seminal root) (4)

Vigor index II = germination $\%$ x seedling dry mass in $\mathrm{mg}$ (shoot + seminal root)

Data related to excel software were sorted and processed and then statistical analysis of the data was performed by SAS JMP software and comparisons of means were performed by Tukey test at $5 \%$ probability level.

\section{Results and Discussion}

The results of data analysis of variance are reported in Table 1. Application of titanium dioxide treatment had a significant effect on all studied traits except seed vigor index I and shoot length. The effect of salinity stress was significant on all traits except shoot, root and seedling weight. The results also showed that all traits except shoot and seedling weight, seed vigor index I were significantly affected by the interaction of titanium dioxide and salinity stress.

Effect of titanium dioxide on germination indices of Echinacea under salinity stress

As shown in Table 2, the application of titanium dioxide treatment improved the germination percentage and rate and mean daily germination compared to the control. Application of titanium dioxide nanoparticle increased the seedling weight from the control with a value of $1.28 \mathrm{mg}$ to $4.26 \mathrm{mg}$ in the treatment of $150 \mathrm{ppm}$ nanoparticles. The application of titanium dioxide had no effect on the shoot weight of Echinacea. The results of this test are the same as the experimental results performed by Tokalloo et al. (2013) on barley and Feizi et al. (2013) on sage. All experimental treatments significantly positively affected shoot length, seedling weight, and root weight compared to the control. The lowest root length was related to the control and the concentration of $150 \mathrm{mg} / \mathrm{l}$ of non-nanoparticles had the best performance, so that it increased the length of root, stem and seedling about three times compared to the control.

\begin{tabular}{|c|c|c|c|c|c|c|c|c|c|c|c|c|c|}
\hline $\begin{array}{l}\text { Source of } \\
\text { variation }\end{array}$ & df & $\begin{array}{l}\text { Seed } \\
\text { vigor } \\
\text { II }\end{array}$ & $\begin{array}{l}\text { Seed } \\
\text { vigor } \\
\text { I }\end{array}$ & $\begin{array}{l}\text { Seedling } \\
\text { length }\end{array}$ & $\begin{array}{l}\text { Root } \\
\text { length }\end{array}$ & $\begin{array}{l}\text { Shoot } \\
\text { length }\end{array}$ & $\begin{array}{l}\text { Seedling } \\
\text { weight }\end{array}$ & $\begin{array}{c}\text { Root } \\
\text { weight }\end{array}$ & $\begin{array}{l}\text { Shoot } \\
\text { weight }\end{array}$ & $\begin{array}{c}\text { Mean } \\
\text { daily } \\
\text { germination }\end{array}$ & $\begin{array}{c}\text { Mean } \\
\text { germination } \\
\text { time }\end{array}$ & $\begin{array}{l}\text { Germination } \\
\text { rate }\end{array}$ & Germination \\
\hline $\mathrm{TiO}_{2}$ & 8 & $117638 * *$ & 25137.69 NS & $158.72 * *$ & $50.52 * *$ & $58.85 * *$ & $6.99 \mathrm{NS}$ & $0.72 * *$ & 5.53 NS & $1.77^{* *}$ & $21.47^{* *}$ & $1.32 * *$ & $781.92 * *$ \\
\hline Salinity & 3 & $4829442 * *$ & $84607.21 * *$ & $829.73 * *$ & $508.05 * *$ & $94.85^{* *}$ & 5.74 NS & 0.52 NS & 8.74 NS & $17.50 * *$ & $20.06 * *$ & $48.48 * *$ & $7542.51 * *$ \\
\hline $\mathrm{TiO} 2 \times$ Salinity & 24 & $434076 * *$ & 26985.32 NS & $43.58 * *$ & $35.76 * *$ & $13.92 * *$ & 5.63 NS & $0.44 * *$ & $4.34 \mathrm{NS}$ & $1.31 * *$ & $11.50 * *$ & $0.84 * *$ & $587.40 * *$ \\
\hline Error & 72 & 36544 & 24260.7 & 8.85 & 6.47 & 2.82 & 4.35 & 0.23 & 4.13 & 0.27 & 0.85 & 0.21 & 121.93 \\
\hline Total & 107 & & & & & & & & & & & & \\
\hline
\end{tabular}

Table 1 - Analysis of variation of nano and bulk titanium dioxide particles on germination and seedling traits of Echinacea

NS, $*$, and $* *$ : No significant, significant at 5 and $1 \%$ probability, respectively. 
Table 2 - Effect of titanium dioxide particles on germination traits of Echinacea under salinity stress

\begin{tabular}{|c|c|c|c|c|c|c|c|c|c|c|c|}
\hline $\begin{array}{l}\mathrm{TiO}_{2} \\
\text { concentration } \\
\mathrm{mg} / \mathrm{l}\end{array}$ & $\begin{array}{l}\text { Vigor } \\
\text { index } \\
\text { II }\end{array}$ & $\begin{array}{l}\text { Vigor } \\
\text { index } \\
1\end{array}$ & $\begin{array}{l}\text { Seedling } \\
\text { length } \\
(\mathrm{mm})\end{array}$ & $\begin{array}{l}\text { Root } \\
\text { length } \\
(\mathrm{mm})\end{array}$ & $\begin{array}{l}\text { Shoot } \\
\text { length } \\
(\mathrm{mm})\end{array}$ & $\begin{array}{l}\text { Seedling } \\
\text { weight } \\
\text { (mg) }\end{array}$ & $\begin{array}{l}\text { Root } \\
\text { weight } \\
\text { (mg) }\end{array}$ & $\begin{array}{l}\text { Shoot } \\
\text { weight } \\
\text { (mg) }\end{array}$ & $\begin{array}{c}\text { Mean } \\
\text { daily } \\
\text { germination } \\
\text { (seed) }\end{array}$ & $\begin{array}{c}\text { Germination } \\
\text { rate } \\
\text { (seed/day) }\end{array}$ & $\begin{array}{c}\text { Germinat- } \\
\text { ion } \\
\text { (\%) }\end{array}$ \\
\hline 0 & $601.46 a b$ & $107.05 \mathrm{a}$ & $7.16 \mathrm{c}$ & $3.19 \mathrm{c}$ & $3.97 \mathrm{~b}$ & $1.28 \mathrm{~b}$ & $0.16 \mathrm{~b}$ & $1.12 \mathrm{a}$ & $2.03 \mathrm{~b}$ & $1.75 \mathrm{~b}$ & $42.66 \mathrm{~b}$ \\
\hline N10 & $826.53 \mathrm{a}$ & $181.13 \mathrm{a}$ & $16.79 a b$ & $6.83 a b$ & 9.95 a & $2.82 \mathrm{ab}$ & $0.84 \mathrm{a}$ & $1.98 \mathrm{a}$ & $3.19 a$ & $2.44 a$ & $67.00 \mathrm{a}$ \\
\hline N50 & $648.57 \mathrm{ab}$ & $171.00 \mathrm{a}$ & $15.50 \mathrm{~b}$ & $5.24 b c$ & $10.25 \mathrm{a}$ & $2.97 \mathrm{ab}$ & $0.89 a$ & $2.08 \mathrm{a}$ & $2.79 \mathrm{a}$ & $2.59 \mathrm{a}$ & $58.33 \mathrm{a}$ \\
\hline N100 & $574.85 \mathrm{~b}$ & $161.40 \mathrm{a}$ & $14.00 \mathrm{~b}$ & $4.09 \mathrm{bc}$ & 9.89 a & $2.60 \mathrm{ab}$ & $0.44 a b$ & $2.15 \mathrm{a}$ & $2.93 \mathrm{a}$ & $2.75 \mathrm{a}$ & $61.66 \mathrm{a}$ \\
\hline N150 & $605.16 a b$ & $282.37 \mathrm{a}$ & $15.05 \mathrm{~b}$ & $5.29 \mathrm{bc}$ & $9.91 \mathrm{a}$ & $4.26 \mathrm{a}$ & $0.49 a b$ & $3.76 \mathrm{a}$ & $2.96 \mathrm{a}$ & $2.56 \mathrm{a}$ & $62.00 \mathrm{a}$ \\
\hline B10 & $811.69 a b$ & $195.43 \mathrm{a}$ & $16.97 \mathrm{ab}$ & $6.67 b$ & $10.31 \mathrm{a}$ & $2.95 \mathrm{ab}$ & $0.80 \mathrm{a}$ & $2.15 \mathrm{a}$ & $3.19 a$ & $2.75 \mathrm{a}$ & $64.33 \mathrm{a}$ \\
\hline B50 & $762.01 \mathrm{ab}$ & $167.62 \mathrm{a}$ & $17.82 \mathrm{ab}$ & $5.97 b c$ & $11.93 \mathrm{a}$ & $2.57 \mathrm{ab}$ & $0.40 \mathrm{ab}$ & $2.17 \mathrm{a}$ & $3.11 \mathrm{a}$ & $2.60 \mathrm{a}$ & $65.33 \mathrm{a}$ \\
\hline B100 & $769.84 \mathrm{ab}$ & $181.81 \mathrm{a}$ & $14.17 \mathrm{~b}$ & $3.89 b c$ & $10.27 \mathrm{a}$ & $2.56 \mathrm{ab}$ & $0.43 a b$ & $2.13 a$ & $3.33 a$ & $2.81 \mathrm{a}$ & $70.00 \mathrm{a}$ \\
\hline B150 & $768.81 \mathrm{ab}$ & $168.33 \mathrm{a}$ & 20.32 a & $10.04 \mathrm{a}$ & $10.27 a$ & $2.54 \mathrm{ab}$ & $0.42 \mathrm{ab}$ & $2.12 \mathrm{a}$ & $3.20 \mathrm{a}$ & $2.82 \mathrm{a}$ & 67.33 a \\
\hline
\end{tabular}

Means, in each column, followed by same letter are not significantly different at the $5 \%$ probability level, using Tukey Test. $n=$ nano, $\mathrm{b}=$ bulk

The effect of salinity stress on germination indices of Echinacea

The results reported in Table 3 show that Echinacea had the highest germination percentage at the level of zero and salinity stress -3 bar, but with increasing salinity stress, the germination percentage decreased significantly. At the stress level of -9 bar, it decreased by $37.5 \%$ compared to the control. The highest germination percentage was related to the control treatment and decreased significantly with increasing salinity stress levels, so that it decreased by 2.5 times compared to the control at -9 bar.

Miri and Mirjalili (2013) stated that one of the ways to priming seed is to use $\mathrm{NaCl}$ salt solution with salinity $1 \mathrm{dS} \mathrm{m}^{-1}$, which in saline areas improves seedling growth rate by up to $20 \%$. They stated that at $1 \mathrm{dS} \mathrm{m}^{-1}$ salinity the germination rate of Echinacea is $57.7 \%$ but with increasing the amount of $\mathrm{NaCl}$ to 6 $\mathrm{dS} \mathrm{m}^{-1}$ salinity the germination rate decreases to about $9.8 \%$.

The highest germination rate was observed in the control treatment and with increasing the intensity of salinity stress, the germination rate decreased significantly. Seeds that are exposed to salinity stress face water shortage, resulting in a decrease in germination rate and percentage under the influence of salinity (Kafi et al., 2005). Seed and impaired storage protein synthesis reduce seed germination (Vigot, 2009). In addition, the toxicity of sodium and chlorine ions in salinity stress play an important role in reducing seed germination (Hanslin and Eggen, 2005). In a study on the effect of different osmotic potentials of sodium chloride and calcium chloride salts on the germination characteristics of Echinacea seeds, it was observed that with increasing salt concentration, all germination traits significantly ( $p \leq 5 \%)$ are reduced, so that in the potential of -9 bar, the percentage and rate of germination decreased by $50 \%$ and seed vigor by $83 \%$ (Ebrahimi Anjeshshi et al., 2011). The inhibitory effects of sodium chloride on seed germination may be due to its direct effect on embryo growth. The researchers found that fetal axis elongation was severely inhibited by high levels of sodium chloride in the irrigation solution. On the

Table 3 - Effect of salinity stress on germination traits of Echinacea

\begin{tabular}{|c|c|c|c|c|c|c|c|c|c|c|c|}
\hline $\begin{array}{c}\text { Salinity } \\
\text { (bar) }\end{array}$ & $\begin{array}{c}\text { Vigor } \\
\text { index } \\
\text { II }\end{array}$ & $\begin{array}{c}\text { Vigor } \\
\text { index } \\
I\end{array}$ & $\begin{array}{l}\text { Seedling } \\
\text { length } \\
(\mathrm{mm})\end{array}$ & $\begin{array}{l}\text { Root } \\
\text { length } \\
(\mathrm{mm})\end{array}$ & $\begin{array}{l}\text { Shoot } \\
\text { length } \\
(\mathrm{mm})\end{array}$ & $\begin{array}{l}\text { Seedling } \\
\text { length } \\
(\mathrm{mg})\end{array}$ & $\begin{array}{l}\text { Root } \\
\text { length } \\
\text { (mg) }\end{array}$ & $\begin{array}{l}\text { Shoot } \\
\text { length } \\
\text { (mg) }\end{array}$ & $\begin{array}{l}\text { Mean daily } \\
\text { germination } \\
\quad \text { (seed) }\end{array}$ & $\begin{array}{c}\text { Germination } \\
\text { rate } \\
\text { (seed/day) }\end{array}$ & $\begin{array}{c}\text { Germination } \\
(\%)\end{array}$ \\
\hline 0 & $335.32 \mathrm{c}$ & $198.97 \mathrm{ab}$ & $21.76 \mathrm{a}$ & $11.71 \mathrm{a}$ & $10.05 \mathrm{~b}$ & $2.53 \mathrm{a}$ & $0.71 \mathrm{a}$ & $1.81 \mathrm{a}$ & $3.76 \mathrm{a}$ & $4.31 \mathrm{a}$ & $78.37 a$ \\
\hline-3 & $1288.88 \mathrm{a}$ & $245.66 \mathrm{a}$ & $18.04 \mathrm{~b}$ & $6.01 b$ & $12.06 \mathrm{a}$ & $3.42 \mathrm{a}$ & $0.39 a$ & $3.03 \mathrm{a}$ & $3.43 \mathrm{a}$ & $2.80 \mathrm{~b}$ & $72.14 \mathrm{a}$ \\
\hline-6 & $741.65 \mathrm{~b}$ & $159.21 \mathrm{ab}$ & $11.41 \mathrm{c}$ & $2.68 \mathrm{c}$ & $8.73 \mathrm{c}$ & $2.49 a$ & $0.49 a$ & $1.99 \mathrm{a}$ & $2.70 \mathrm{~b}$ & $1.97 \mathrm{c}$ & $56.74 \mathrm{~b}$ \\
\hline-9 & $464.78 c$ & $114.43 \mathrm{~b}$ & $10.02 \mathrm{c}$ & $2.36 \mathrm{c}$ & $7.72 \mathrm{c}$ & $2.47 a$ & $0.57 a$ & $1.90 \mathrm{a}$ & $1.95 \mathrm{c}$ & $1.17 \mathrm{~d}$ & $41.03 \mathrm{c}$ \\
\hline
\end{tabular}

Means, in each column, followed by same letter are not significantly different at the $5 \%$ probability level- using Tukey Test. $n=$ nano, $b=$ bulk. 
other hand, sodium chloride, due to inhibition of water uptake by seeds, slows down vital activities in the seed and increases rooting time (Mohammadi et al., 2011).

The mean daily germination trait had the best performance at zero and -3 bar the salinity stress level, but decreased significantly with increasing the stress level and reached the lowest level at -9 bar. No significant difference was observed between stem levels in shoot weight, root weight and seedling weight. However, numerically, yield in shoot weight and seedling weight at the level of 3-bar stress showed a slight increase compared to the control, which decreased with increasing stress intensity. The highest shoot length was observed at the level of -3 bar salinity stress, which was higher than the control. The root length in control had the highest value and decreased sharply with increasing the stress level, so that the root length at the level of -9 bar drought load was reduced about 10 times compared to the control. Seedling length was highest at zero stress level, but with increased stress level to -9 bar, seedling length was reduced by half. The results of research on sage showed a decrease in root and stem length with increasing osmotic stress (Stephanie et al., 2005). The results of studies on sage and ten species of medicinal plants showed the negative effect of salinity stress on plant length (Fallahi et al., 2009).

The best seed vigor index I was seen at the stress level of -3 bar, which was not significantly different from the control level and -6 bar. But compared to the -9 bar stress level, it was about 2 times higher. Seed vigor index II had the best performance at -3 bar stress and a significant decrease was seen at -6 bar level. Seed vigor index II in control and -9 bar stress had the lowest value (Table 3 ).

Interaction of titanium dioxide and salinity stress on germination indices of Echinacea

As can be seen from the results reported in Table 4 , the use of titanium dioxide treatment increased the germination percentage at high salinity stress condition. In the absence of nano titanium dioxide at -6 and -9 bar level salinity stress, no germination occurred at all, but with the application of titanium dioxide, the germination percentage increased significantly in the mentioned stress intensities. So that in the control treatment with salinity stress -9 bar germination was zero; however, in the treatments of 50 $\mathrm{mg} / \mathrm{I}$ non-nanoparticles and $150 \mathrm{mg} / \mathrm{I}$ nanoparticles at the same stress level, germination was observed $50.66 \%$.

Contrary to the results of the present experiment, Zheng et al. (2005) reported that titanium dioxide nanoparticles absorb more water in spinach seeds, thus accelerating seed germination. Khot et al. (2012) pointed out that the main reason for the increase in plant growth rate in response to titanium dioxide nanoparticles is the production of sterile radiation oxygen, which increases seed resistance to stress and improves water and oxygen penetration in accelerating germination.

In terms of germination rate, the application of titanium dioxide increased the germination rate at high levels of salinity stress compared to the control and the treatment of $10 \mathrm{mg} / \mathrm{l}$ of non-nanoparticles maintained the germination rate during increasing salinity stress. However, under non-stress conditions, the concentration of $150 \mathrm{mg} / \mathrm{l}$ of non-nanoparticles had a higher performance than all experimental treatments.

The mean germination time in Echinacea seeds decreased with increasing salinity stress level. Due to this, a limited number of seeds germinated at high salinity stress levels in the first days of the experiment and during the counting days, due to severe salinity, the germination process stopped; however, at low stress levels, the germination process continued until the last days of counting, which increased the mean germination time at low salinity stress levels.

The application of titanium dioxide caused the mean daily germination during the increasing process of salinity stress to be higher than the control. In general, increasing the salinity stress level from zero to 9 bar reduced the mean daily germination; however, among the experimental treatments, $150 \mathrm{mg} / \mathrm{l}$ nanoparticles and $50 \mathrm{mg} / \mathrm{l}$ non-nanoparticles were able to better inhibit the decrease in germination mean due to increased salinity stress.

According to the results reported in Table 5, the best treatment for stem weight was $150 \mathrm{mg} / \mathrm{l}$ nanoparticles at a stress level of -3 bar. No significant difference was observed between other experimental treatments; However, treatments of $100 \mathrm{mg} / \mathrm{l}$ nanoparticles and $150 \mathrm{mg} / \mathrm{l}$ of non-nanoparticles had 6 times higher shoot weight at the stress level. Application of titanium dioxide treatment increased root weight compared to control at high stress levels. There was no significant difference in non-nano and control treatments at different levels of salinity stress in seedling weight. 
Table 4 - Interaction effect of titanium dioxide particles and salinity on germination traits of Echinacea

\begin{tabular}{|c|c|c|c|c|c|}
\hline $\mathrm{TiO}_{2}(\mathrm{mg} / \mathrm{l})$ & Salinity (bar) & $\begin{array}{c}\text { Mean daily } \\
\text { germination (seed) }\end{array}$ & $\begin{array}{c}\text { Mean germination } \\
\text { time (day) }\end{array}$ & $\begin{array}{c}\text { Germination rate } \\
\text { (seed/day) }\end{array}$ & $\begin{array}{c}\text { Germination } \\
(\%)\end{array}$ \\
\hline \multirow[t]{4}{*}{0} & 0 & $4.06 a b$ & $6.46 \mathrm{c}-\mathrm{g}$ & $4.31 \mathrm{abc}$ & $85.33 a b$ \\
\hline & -3 & 3.87 a-d & $9.04 \mathrm{abc}$ & $2.57 \mathrm{~d}-\mathrm{i}$ & $81.33 \mathrm{a}-\mathrm{d}$ \\
\hline & -6 & $0.19 \mathrm{fg}$ & $0.42 \mathrm{~h}$ & $0.11 \mathrm{jk}$ & $4.00 \mathrm{fg}$ \\
\hline & -9 & g 0 & ho & $\mathrm{k} 0$ & g 0 \\
\hline \multirow[t]{4}{*}{$10 n$} & 0 & 3.55 a-e & $7.28 \mathrm{a}-\mathrm{g}$ & $3.04 \mathrm{c}-\mathrm{g}$ & 74.66 a-e \\
\hline & -3 & 3.49 a-e & $7.36 \mathrm{a}-\mathrm{g}$ & $2.92 \mathrm{c}-\mathrm{h}$ & 73.33 a-e \\
\hline & -6 & 3.36 a-e & 8.95 a-d & $2.39 \mathrm{f}-\mathrm{i}$ & 70.66 a-e \\
\hline & -9 & 2.34 b-e & $9.48 a b$ & $1.41 \mathrm{~h}-\mathrm{k}$ & 49.33 b-e \\
\hline \multirow[t]{4}{*}{$50 n$} & 0 & 3.87 a-d & $5.39 \mathrm{fg}$ & $4.57 a b$ & 80 a-d \\
\hline & -3 & 2.98 a-e & 7.06 b-g & $2.54 \mathrm{e}-\mathrm{i}$ & 62.66 a-e \\
\hline & -6 & 2.41 a-e & $6.99 \mathrm{~b}-\mathrm{g}$ & $2.26 \mathrm{f}-\mathrm{i}$ & 50.66 a-e \\
\hline & -9 & 1.90 ef & 8.90 a-d & $1.23 \mathrm{ijk}$ & 40.00 ef \\
\hline \multirow[t]{4}{*}{$100 n$} & 0 & $4.12 \mathrm{a}$ & $6.43 \mathrm{c}-\mathrm{g}$ & $4.92 \mathrm{a}$ & $86.66 \mathrm{a}$ \\
\hline & -3 & 3.49 a-e & $6.42 \mathrm{c}-\mathrm{g}$ & $3.19 b-f$ & 73.33 a-e \\
\hline & -6 & $2.22 \mathrm{de}$ & 8.43 a-e & $1.63 \mathrm{~g}-\mathrm{j}$ & $46.66 \mathrm{de}$ \\
\hline & -9 & 1.90 ef & 8.39 a-f & $1.26 \mathrm{ijk}$ & 40.00 ef \\
\hline \multirow[t]{4}{*}{$150 n$} & 0 & 3.36 a-e & $4.84 \mathrm{~g}$ & $4.09 a-d$ & 69.33 a-e \\
\hline & -3 & 3.11 a-e & $7.34 \mathrm{a-g}$ & $2.58 \mathrm{~d}-\mathrm{i}$ & 65.33 a-e \\
\hline & -6 & 2.98 a-e & $7.58 \mathrm{a}-\mathrm{g}$ & $2.26 \mathrm{f}-\mathrm{i}$ & 62.66 a-e \\
\hline & -9 & 2.41 a-e & $10.18 \mathrm{a}$ & $1.31 \mathrm{ijk}$ & 50.66 a-e \\
\hline \multirow[t]{4}{*}{ B10 } & 0 & 3.49 a-e & $5.72 \mathrm{efg}$ & $4.33 \mathrm{abc}$ & 70.66 a-e \\
\hline & -3 & 3.55 a-e & $6.98 \mathrm{~b}-\mathrm{g}$ & $3.02 \mathrm{c}-\mathrm{g}$ & 74.66 a-e \\
\hline & -6 & 3.17 a-e & 8.63 a-e & $2.32 \mathrm{f}-\mathrm{i}$ & 66.66 a-e \\
\hline & -9 & $2.15 \mathrm{de}$ & $9.08 \mathrm{abc}$ & $1.31 \mathrm{ijk}$ & $45.33 \mathrm{~d}-\mathrm{e}$ \\
\hline \multirow[t]{4}{*}{ B50 } & 0 & $3.80 \mathrm{a}-\mathrm{d}$ & $7.13 \mathrm{~b}-\mathrm{g}$ & $4.56 a b$ & $80.00 \mathrm{a}-\mathrm{d}$ \\
\hline & -3 & 2.85 a-e & 8.53 a-e & $2.045 \mathrm{f}-\mathrm{i}$ & 60.00 a-e \\
\hline & -6 & 3.36 a-e & 8.60 a-e & $2.36 \mathrm{f}-\mathrm{i}$ & 70.66 a-e \\
\hline & -9 & 2.41 a-e & $9.40 \mathrm{abc}$ & $1.41 \mathrm{~h}-\mathrm{k}$ & 50.66 a-e \\
\hline \multirow[t]{4}{*}{$100 \mathrm{~b}$} & 0 & 3.42 a-e & $5.96 \mathrm{~d}-\mathrm{g}$ & 3.93 a-e & 72.00 a-e \\
\hline & -3 & $4.00 \mathrm{abc}$ & $7.37 \mathrm{a}-\mathrm{g}$ & $3.36 b-f$ & $84.00 \mathrm{abc}$ \\
\hline & -6 & 3.61 a-e & 8.20 a-f & $2.66 \mathrm{~d}-\mathrm{i}$ & 76.00 a-e \\
\hline & -9 & $2.28 \mathrm{cde}$ & $10.18 \mathrm{a}$ & $1.30 \mathrm{ijk}$ & 48.00 cde \\
\hline \multirow[t]{4}{*}{$150 \mathrm{~b}$} & 0 & $4.12 \mathrm{a}$ & $6.67 \mathrm{~b}-\mathrm{g}$ & $5.03 \mathrm{a}$ & $86.66 \mathrm{a}$ \\
\hline & -3 & 3.55 a-e & $7.37 \mathrm{a}-\mathrm{g}$ & $2.95 \mathrm{c}-\mathrm{g}$ & 74.66 a-e \\
\hline & -6 & 2.98 a-e & $9.10 \mathrm{abc}$ & $1.99 \mathrm{f}-\mathrm{i}$ & $62.66 \mathrm{de}$ \\
\hline & -9 & $2.15 \mathrm{de}$ & $9.06 \mathrm{abc}$ & $1.32 \mathrm{ijk}$ & $45.33 \mathrm{de}$ \\
\hline
\end{tabular}

Means, in each column, followed by same letter are not significantly different at the $5 \%$ probability level, using Tukey Test. $n=$ nano, $b=$ bulk

Feizi et al. (2012) stated that titanium dioxide treatment had no significant effect on shoot dry weight, seedling, vigor index I and II of wheat; However, the application of titanium dioxide at all levels caused a significant increase in root dry weight and the highest root dry weight was observed in the treatments of 2 and $500 \mathrm{mg} / \mathrm{l}$ non-nanoparticles and $100 \mathrm{mg} / \mathrm{l}$ nanoparticles.

There was a significant difference between control treatment and different concentrations of titanium dioxide in shoot length, especially at high salinity stress levels. In general, in all treatments, -3 bar level salinity stress increased stem length.

Studies on seedling length also showed that the application of titanium dioxide had a significant positive effect on non-use at high stress levels and in most experimental treatments at the level of -3 bar the salinity stress compared to the non-stress state, seedling length increased shows. Treatment of 150 $\mathrm{mg} / \mathrm{l}$ non-nanoparticles in the process of increasing salinity stress from zero to -9 bar was able to maintain the root length to a higher value. The results of Paravar and Omidi (2014) and Motevasel et al. (2014) showed that with increasing salinity stress, seedling 
Table 5 - Interaction effect of titanium dioxide particles and salinity on seedling traits of Echinacea

\begin{tabular}{|c|c|c|c|c|c|c|c|c|c|}
\hline $\mathrm{TiO}_{2}(\mathrm{mg} / \mathrm{l})$ & $\begin{array}{c}\text { Salinity } \\
\text { (bar) }\end{array}$ & $\begin{array}{c}\text { Vigor } \\
\text { index II }\end{array}$ & $\begin{array}{l}\text { Vigor } \\
\text { index I }\end{array}$ & $\begin{array}{l}\text { Shoot } \\
\text { length } \\
(\mathrm{mm})\end{array}$ & $\begin{array}{l}\text { Root } \\
\text { length } \\
(\mathrm{mm})\end{array}$ & $\begin{array}{l}\text { Seedling } \\
\text { length } \\
(\mathrm{mm})\end{array}$ & $\begin{array}{c}\text { Seedling } \\
\text { weight } \\
\text { (mg) }\end{array}$ & $\begin{array}{c}\text { Root } \\
\text { weight } \\
\text { (mg) }\end{array}$ & $\begin{array}{c}\text { Shoot } \\
\text { weight } \\
\text { (mg) }\end{array}$ \\
\hline \multirow[t]{4}{*}{0} & 0 & $1622.13 \mathrm{ab}$ & $215.28 \mathrm{ab}$ & $19.03 \mathrm{~b}-\mathrm{g}$ & 10.03 b-e & $9.00 \mathrm{~b}-\mathrm{g}$ & $2.52 \mathrm{~b}$ & $0.45 a b$ & $2.07 \mathrm{~b}$ \\
\hline & -3 & $783.73 \mathrm{~d}-\mathrm{i}$ & $212.92 a b$ & $9.63 \mathrm{ghi}$ & $2.73 \mathrm{~d}-\mathrm{g}$ & $6.90 \mathrm{fg}$ & $2.61 b$ & $0.20 a b$ & $2.41 a b$ \\
\hline & -6 & k 0 & b 0 & i 0 & g 0 & ho & b 0 & $0.00 \mathrm{~b}$ & b 0 \\
\hline & -9 & k 0 & b 0 & i 0 & g 0 & ho & b 0 & $0.00 \mathrm{~b}$ & b 0 \\
\hline \multirow[t]{4}{*}{$10 n$} & 0 & $149.85 \mathrm{jk}$ & $174.94 a b$ & $19.70 b-f$ & $11.70 \mathrm{~b}$ & $8.00 \mathrm{c}-\mathrm{g}$ & $2.30 \mathrm{~b}$ & $0.81 a b$ & $1.49 \mathrm{~b}$ \\
\hline & -3 & $1663.06 \mathrm{a}$ & $188.41 \mathrm{ab}$ & $22.70 \mathrm{bcd}$ & $9.30 \mathrm{~b}-\mathrm{f}$ & $13.40 \mathrm{abc}$ & $2.56 \mathrm{~b}$ & ab0.41 & $2.15 \mathrm{~b}$ \\
\hline & -6 & 923.46 c-h & $166.25 \mathrm{~b}$ & $13.13 \mathrm{~d}-\mathrm{h}$ & 4.16 b-g & 8.96 b-g & $2.34 \mathrm{~b}$ & ab0.38 & $1.95 \mathrm{~b}$ \\
\hline & -9 & $569.73 \mathrm{f}-\mathrm{k}$ & $194.92 \mathrm{ab}$ & $11.64 \mathrm{fgh}$ & 2.18 efg & $9.45 \mathrm{~b}-\mathrm{g}$ & $3.08 \mathrm{ab}$ & $0.75 a b$ & $2.33 \mathrm{~b}$ \\
\hline \multirow[t]{4}{*}{$50 n$} & 0 & $135.36 \mathrm{jk}$ & $197.22 \mathrm{ab}$ & $16.93 \mathrm{~b}-\mathrm{h}$ & 7.23 b-g & $9.70 \mathrm{a}-\mathrm{g}$ & $2.46 \mathrm{~b}$ & $0.85 a b$ & $1.61 \mathrm{~b}$ \\
\hline & -3 & $1414.00 \mathrm{abc}$ & $183.61 \mathrm{ab}$ & $22.76 \mathrm{bcd}$ & 7.80 b-g & $14.96 \mathrm{a}$ & $2.91 \mathrm{ab}$ & $0.38 a b$ & $2.53 \mathrm{ab}$ \\
\hline & -6 & $597.13 \mathrm{f}-\mathrm{k}$ & $157.61 \mathrm{~b}$ & $11.75 \mathrm{fgh}$ & $2.90 \mathrm{~d}-\mathrm{g}$ & 8.85 b-g & $3.06 a b$ & $0.88 a b$ & $2.18 b$ \\
\hline & -9 & $447.80 \mathrm{~g}-\mathrm{k}$ & $145.54 \mathrm{~b}$ & $10.55 \mathrm{fgh}$ & $3.03 \mathrm{c}-\mathrm{g}$ & $7.51 \mathrm{efg}$ & $2.45 a b$ & $0.45 a b$ & $2.00 \mathrm{~b}$ \\
\hline \multirow[t]{4}{*}{$100 n$} & 0 & $169.84 \mathrm{ijk}$ & $219.93 a b$ & $19.60 \mathrm{~b}-\mathrm{f}$ & 7.03 b-g & 12.56 a-e & $2.54 \mathrm{~b}$ & $0.65 a b$ & $1.88 \mathrm{~b}$ \\
\hline & -3 & 1243.73 a-e & $195.29 a b$ & $17.00 \mathrm{~b}-\mathrm{h}$ & 4.23 b-g & 12.76 a-e & $2.67 \mathrm{~b}$ & $0.30 a b$ & $2.36 \mathrm{ab}$ \\
\hline & -6 & $437.20 \mathrm{~g}-\mathrm{k}$ & $133.38 \mathrm{~b}$ & 8.10 hi & $1.33 \mathrm{fg}$ & $6.73 \mathrm{~g}$ & $2.77 \mathrm{~b}$ & $0.33 a b$ & $2.44 a b$ \\
\hline & -9 & 448.64 g-k & 97.02 b & $11.31 \mathrm{fgh}$ & 3.78 b-g & $7.52 \mathrm{efg}$ & $2.42 \mathrm{~b}$ & $0.50 a b$ & $1.92 \mathrm{~b}$ \\
\hline \multirow[t]{4}{*}{$150 n$} & 0 & $160.93 \mathrm{ijk}$ & $173.66 \mathrm{ab}$ & $23.16 b c$ & $11.23 \mathrm{bc}$ & $11.93 \mathrm{a}-\mathrm{g}$ & $2.48 \mathrm{~b}$ & $0.71 a b$ & $1.77 \mathrm{~b}$ \\
\hline & -3 & $944.00 \mathrm{c}-\mathrm{h}$ & $681.26 \mathrm{a}$ & $14.43 \mathrm{c}-\mathrm{h}$ & 4.86 b-g & $9.56 \mathrm{a}-\mathrm{g}$ & $9.71 \mathrm{a}$ & $0.70 a b$ & $9.01 \mathrm{a}$ \\
\hline & -6 & 840.40 c-h & 154.45 b & $13.36 \mathrm{~d}-\mathrm{h}$ & $2.86 \mathrm{~d}-\mathrm{g}$ & 10.50 a-g & $2.44 \mathrm{~b}$ & $0.25 a b$ & $2.19 \mathrm{~b}$ \\
\hline & -9 & $475.33 \mathrm{~g}-\mathrm{k}$ & $120.09 \mathrm{~b}$ & 9.26 hi & 2.20 efg & $7.66 \mathrm{~d}-\mathrm{g}$ & $2.40 \mathrm{~b}$ & $0.32 a b$ & $2.08 \mathrm{~b}$ \\
\hline \multirow[t]{4}{*}{ B10 } & 0 & $139.44 \mathrm{jk}$ & $188.77 \mathrm{ab}$ & $19.63 b-f$ & $10.86 \mathrm{bcd}$ & $8.77 \mathrm{~b}-\mathrm{g}$ & $2.67 b$ & $0.83 a b$ & $1.84 \mathrm{~b}$ \\
\hline & -3 & $1632.40 \mathrm{a}$ & $202.61 \mathrm{ab}$ & 21.86 b-e & $9.13 b-f$ & 12.73 a-e & $2.70 \mathrm{~b}$ & $0.48 a b$ & $2.22 \mathrm{~b}$ \\
\hline & -6 & $896.00 \mathrm{c}-\mathrm{h}$ & $282.26 \mathrm{ab}$ & $13.60 \mathrm{c}-\mathrm{h}$ & 4.60 b-g & 9.04 b-g & $3.04 a b$ & $0.78 a b$ & $2.25 \mathrm{~b}$ \\
\hline & -9 & $579.04 \mathrm{f}-\mathrm{k}$ & $108.09 \mathrm{~b}$ & $12.81 \mathrm{e}-\mathrm{h}$ & 2.10 efg & $10.70 \mathrm{a}-\mathrm{g}$ & $2.41 \mathrm{~b}$ & $0.12 \mathrm{~b}$ & $2.28 \mathrm{~b}$ \\
\hline \multirow[t]{4}{*}{ B50 } & 0 & $200.85 \mathrm{ijk}$ & $213.36 a b$ & $24.83 \mathrm{~b}$ & $10.80 \mathrm{bcd}$ & $14.03 \mathrm{ab}$ & $2.66 \mathrm{~b}$ & $0.66 a b$ & $1.99 \mathrm{~b}$ \\
\hline & -3 & 1166.80 a-f & $155.04 \mathrm{~b}$ & $19.33 \mathrm{e}-\mathrm{g}$ & $6.83 \mathrm{~b}-\mathrm{g}$ & 12.83 a-e & $2.68 \mathrm{~b}$ & $0.37 a b$ & $2.31 \mathrm{~b}$ \\
\hline & -6 & 1044.00 a-g & $173.58 \mathrm{ab}$ & $14.93 \mathrm{c}-\mathrm{h}$ & $2.80 \mathrm{~d}-\mathrm{g}$ & $12.13 \mathrm{a}-\mathrm{g}$ & $2.49 \mathrm{~b}$ & $0.21 a b$ & $2.27 \mathrm{~b}$ \\
\hline & -9 & 636.40 e-j & $128.49 b$ & 12.20 e-h & 3.46 b-g & $8.73 \mathrm{~b}-\mathrm{g}$ & $2.46 \mathrm{~b}$ & $0.35 a b$ & $2.11 b$ \\
\hline \multirow[t]{4}{*}{$100 \mathrm{~b}$} & 0 & $114.96 \mathrm{jk}$ & $198.16 a b$ & $15.93 \mathrm{~b}-\mathrm{h}$ & 7.80 b-g & $8.13 \mathrm{c}-\mathrm{g}$ & $2.74 b$ & $0.78 a b$ & $1.96 \mathrm{~b}$ \\
\hline & -3 & $1451.60 \mathrm{abc}$ & $215.37 \mathrm{ab}$ & $17.30 \mathrm{~b}-\mathrm{h}$ & 4.20 b-g & 13.10 a-d & $2.56 \mathrm{~b}$ & $0.34 a b$ & $2.22 \mathrm{~b}$ \\
\hline & -6 & 1003.06 b-g & $199.90 \mathrm{ab}$ & $12.96 \mathrm{e}-\mathrm{h}$ & 2.13 efg & 10.83 a-g & $2.61 \mathrm{~b}$ & $0.30 a b$ & $2.31 \mathrm{~b}$ \\
\hline & -9 & 509.74 g-k & $113.80 \mathrm{~b}$ & $10.50 \mathrm{fgh}$ & $1.43 \mathrm{fg}$ & 9.03 b-g & $2.34 \mathrm{~b}$ & $0.29 a b$ & $2.04 \mathrm{~b}$ \\
\hline \multirow[t]{4}{*}{$150 b$} & 0 & 324.68 h-k & $209.42 a b$ & $37.06 \mathrm{a}$ & $28.70 \mathrm{a}$ & $8.36 \mathrm{c}-\mathrm{g}$ & $2.41 \mathrm{~b}$ & $0.70 a b$ & $1.71 \mathrm{~b}$ \\
\hline & -3 & $1300.66 \mathrm{a}-\mathrm{d}$ & $176.44 \mathrm{ab}$ & 17.33 b-h & 5.03 b-g & $12.30 \mathrm{a}-\mathrm{f}$ & $2.38 \mathrm{~b}$ & $0.30 a b$ & $2.07 \mathrm{~b}$ \\
\hline & -6 & $933.60 \mathrm{c}-\mathrm{h}$ & $165.46 a b$ & 14.90 c-h & $3.33 \mathrm{c}-\mathrm{g}$ & $11.56 \mathrm{a}-\mathrm{g}$ & $2.66 \mathrm{~b}$ & $0.29 a b$ & $2.37 a b$ \\
\hline & -9 & $516.30 \mathrm{~g}-\mathrm{k}$ & $122.01 \mathrm{~b}$ & $11.98 \mathrm{fgh}$ & $3.10 \mathrm{c}-\mathrm{g}$ & 8.87 b-g & $2.71 \mathrm{~b}$ & $0.38 a b$ & $2.32 \mathrm{~b}$ \\
\hline
\end{tabular}

Means, in each column, followed by same letter are not significantly different at the $5 \%$ probability level- using Tukey Test. $n=$ nano, $b=$ bulk

length, root length and seedling dry weight decreased.

In Seed Vigor Index II, all treatments containing titanium dioxide, salinity stress -3 bar made a significant positive difference compared to the control, but in the conditions without stress, the control had better performance. At high salinity stress levels, the application of titanium dioxide significantly increased the seed vigor index II compared to the time of nonuse.

\section{Conclusions}

Investigation of the main effect of titanium dioxide treatment in testing the effect of nano and nonnano titanium dioxide on germination of Echinacea under salinity stress showed that the use of this treatment in all concentrations, measured indices (except increased seed vigor indices) increased compared to the control treatment. Echinacea tolerated salinity stress up to -3 bar in germination percentage, 
mean germination time, shoot length, seed germination index I and II, and sometimes even at -3 bar stress observed better yield than the control. But germination rate, root and seedling length were strongly affected by salinity stress. The interaction of titanium dioxide and salinity stress treatments showed that although in the increasing trend of salinity stress intensity all studied traits were significantly reduced compared to non-stress conditions, but the application of titanium dioxide treatment in nano and nonnano state in -6 and -9 bar salinity improved significant yield of Echinacea seeds and seedlings in all traits compared to the control. Therefore, the positive effects of using titanium dioxide in mitigating the negative effects of salinity stress on the seeds and seedlings of Echinacea can be a useful and promising solution to solve this problem. Further research is needed to determine the physiological and molecular effects of this substance on the metabolism of plant resistance to salinity stress.

\section{References}

ABDEL LATEF A.A., SRIVASTAVA A.K., ABD EL-SADEK M.S., KORDROSTAMI M., TRAN L.-S.P., 2018 - Titanium dioxide nanoparticles improve growth and enhance tolerance of broad bean plants under saline soil conditions. Land Degrad. Develop., 29: 1065-1073

AMIRI B., REZVANI MOGHADAM P., AHYAEI H., FALLAHI J., AGHWANI SHAJARI M., 2010 - Effect of osmotic and salinity stresses on germination and seedling growth indices of Echinacea purpurea and Cynara scoolymus. J. Environ. Stress Agric. Sci., 3(2): 165-176.

AZIMI R., JANKJU BORZELABAD M., FEIZI H., AZIMI A., 2014 - Interaction of $\mathrm{SiO}_{2}$ nanoparticles with seed prechilling on germination and early seedling growth of tall wheatgrass (Agropyron elongatum L.). - Polish J. Chem. Technol., 16(3): 25-29.

EBRAHIMI ANJESHSHI Z., DASHTI M., SHARIATI M., 2011 Effect of different osmotic potentials of sodium chloride and calcium chloride salts on germination characteristics of Echinacea purpurea seeds. - Proc. Second Nat. Conf. on Seed Science and Technology, Islamic Azad University, 4-5 November, Mashhad.

FALLAHI J., EBADI M.T., GHORBANI R., 2009 - The effects of salinity and drought stresses on germination and seedling growth of clary. - Environ. Stress Agric. Sci., 1(1): 57-67.

FARAJI J., SEPEHRI A., 2019 - Ameliorative effects of $\mathrm{TiO}_{2}$ nanoparticles and sodium nitroprusside on seed germination and seedling growth of wheat under PEG-stimulated drought stress. - J. Seed Sci., 41: 309-317.

FARAVANI M., GHOLAMI B., FEIZI H., 2016 - Agronomy of Echinacea. - University of Torbat, Heydarieh Press, pp.
83.

FEIZI H., AGHELI N., SAHABI H., 2020 - Titanium dioxide nanoparticles alleviate cadmium toxicity in lentil (Lens culinaris Medic) seeds. - Acta Agric Slovenica, 116: 5968.

FEIZI H., AMIRMORADI SH., ABDOLLAHI F., JAHEDI POUR S., 2013 - Comparative effects of nanosized and bulk titanium dioxide concentrations on medicinal plant Salvia officinalis L. - Ann. Rev. Res. Biol., 3(4): 814-824.

FEIZI H., REZVANI MOGHADDAM P., SHAHTAHMASSEBI N., FOTOVAT A., 2012 - Impact of bulk and nanosized titanium dioxide $\left(\mathrm{TiO}_{2}\right)$ on wheat seed germination and seedling growth. - Biol. Trace Elem. Res., 146(1): 101106.

GOHARI G., MOHAMMADI A., AKBARI A., PANAHIRAD S., DADPOUR M.R., FOTOPOULOS V., KIMURA S., 2020 Titanium dioxide nanoparticles ( $\mathrm{TiO}_{2} \mathrm{NPS}$ ) promote growth and ameliorate salinity stress effects on essential oil profile and biochemical attributes of Dracocephalum moldavica. - Sci. Rep., 10: 912.

HANSLIN H.M., EGGEN T., 2005 - Salinity tolerance during germination of seashore halophytes and salt-tolerant grass cultivars. - Seed Sci. Res., 15: 43-50.

ISTA, 2009 - ISTA rules. - International Seed Testing Association, Zuric, Switzerland.

KAFI M., NEZAMI A., HOSSEINI H., MASOUMI A., 2005 Physiological effects of drought stress induced by polyethylene glycol on germination of lentil genotypes. Iranian J. Crop Res., 3(2): 91-101.

KAMALI M., SHOOR M., FEIZI H., 2018 - Impacts of nanosized and bulk titanium dioxide on flowering and morphophysiological traits of petunia (Petunia hybrida) under salinity stress. - J. Hort. Sci., 32: 199-212.

KARAMI A., SEPEHRI A., 2108 - Nano titanium dioxide and nitric oxide alleviate salt induced changes in seedling growth, physiological and photosynthesis attributes of barley. - Zemdirbyste Agric., 105: 123-132.

KHAN M.N., 2016 - Nano-titanium Dioxide (Nano-TiO ${ }_{2}$ ) mitigates $\mathrm{NaCl}$ stress by enhancing antioxidative enzymes and accumulation of compatible solutes in tomato (Lycopersicon esculentum Mill.). - J. Plant Sci., 11: 1-11.

KHOT L.R., SANKARAN S., MAJA J., EHSANI R., SCHUSTER E.W., 2012 - Applications of nanomaterials in agricultural production and crop protection: A review. - Crop Prot., 35: 64-70.

LYU S., WEI X., CHEN J., WANG C., WANG X., PAN D., 2017 Titanium as a beneficial element for crop production. Frontier in Plant Sci., 8: 1-19.

MAGUIRE I.D., 1982 - Speed of germination - Aid in selection and evaluation for seedling emergence and vigor. Crop Sci., 22: 177-176.

MATTHEWS S., KHAJEH-HOSSEINI M., 2007 - Length of the lag period of germination and metabolic repair explain vigor differences in seed lots of maize (Zea mays). Seed Sci. Technol., 35: 200-212.

MIRI Y., MIRJALILI S.A., 2013 - Effects of salinity stress on 
seed germination and some physiological traits in primary stages of growth in purple coneflower (Echinacea purpurea). - Inter. J. Agron. Plant Prod., 4(1): 142-146.

MOHAMMADI N., GHASEMI GHAHSAREH M., BAHARVAND

A., 2011 - Study of salinity tolerance of seven ornamental plants in the germination stage of seed. - Proc. 7th Iranian Congress of Horticultural Sciences, September 5-17, Isfahan. (In Persian).

MOTEVASEL N., ROOHI V., MOHAMMAD KHANI A., 2014 Effect of osmotic pretreatment on primrose seed germination at different levels of salinity stress. - Proc. Second National Conference on Medicinal Plants and Sustainable Agriculture, September 22, Hamedan. (In Persian).

NASIR KHAN M., 2016 - Nano-titanium dioxide (Nano-TiO ${ }_{2}$ ) mitigates $\mathrm{NaCl}$ stress by enhancing antioxidative enzymes and accumulation of compatible solutes in tomato (Lycopersicon esculentum Mill.). - J. Plant Sci., 11: 1-11.

NAVARRO E., BAUN A., BEHRA R., HARTMANN N.B., FILSER J., MIAO A., QUIGG A., SANTSCHI P.H., SIGG L., 2008 Environmental behavior and ecotoxicity of engineered nanoparticles to alga plants, and fungi. - Ecotoxicology, 17: 372-386.

PARAVAR A., OMIDI H., 2104 - Investigation of the effect of priming duration on germination characteristics of Echinacea angustifolia L. under salinity stress. - Proc. First Inter. Congress and the 13th National Congress of Agronomy and Plant Breeding and the Third Conference on Seed Science and Technology, September 4-6, Karaj. (In Persian).

RAMAN P., PATINO L.C., NAIR M.G., 2004 - Evaluation of metal and microbial contamination in botanical supplements. - J. Agric. Food Chem., 52: 7822-7827.
RICHARDS L.A., 1954 - Diagnosis and improvement of saline and alkali soils. - Agriculture Handbook, USDA, Handbook No. 60

SANDRA C.M., 2004 - Echinacea; The genus Echinacea. Med Arom. Plants-Indust. Pro., 39: 271.

STEPHANIE E.B., SVOBODA V.P., PAUL A.T., MARC W.V.I., 2005 - Controlled drought affects morphology and anatomy of Salvia solendens. - J. Amer. Soc. Hort. Sci., 130(5): 775-781.

SUN L.Z., CURRIER N.L., MILLER S.C., 1999 - The American coneflower: a prophylactic role involving non specific immunity. - J. Alternative Compl. Med., 5: 437-446.

TOKALLOO S., DAVOODI D., OMIDI M., EBRAHIMI M.A., ROOZBEH F., RASOOLNIA A., 2013 - Effect of $\mathrm{TiO}_{2}$ nanoparticles on germination traits and cytogenetic characteristics of barley. - J. Agric. Biotech., 5(1): 13-25.

VASHISTH A., NAGARAJAN S., 2010 - Effect on germination and early growth characteristics in sunflower (Helianthus annuus) seed exposed to static magnetic field. - J. Plant Physiol., 167: 149-156.

VIGOT E.L., ALMEIDA T.D., CHAGAS R.M., PONTE L.F.A., VIÉGAS R.A., SILVEIRA J.A.G., 2009 - Source-sink regulation of cotyledonary reserve mobilization during cashew (Anacardium occidentale) seedling establishment under NaCl salinity. - J. Plant Physiol., 166(1): 8089.

YOUNES N.A., SHOKRY HASSAN H., ELKADY MARWA F., HAMED A.M., DAWOOD MONA F.A., 2020 - Impact of synthesized metal oxide nanomaterials on seedlings production of three Solanaceae crops. - Heliyon, 6. 03188.

ZHENG L., HONG F., LU S., LIU C., 2005 - Effect of nano-TiO, on strength of naturally aged seeds and growth of Spinach. - Biol. Trace Elem. Res., 105: 83-91.90 